\title{
Model Pengembangan Mutu Pendidikan (Tinjauan Konsep Mutu Kaoru Ishikawa)
}

\author{
Roni Harsoyo \\ STAI Miftahul Ula Nglawak Kertosono Nganjuk, Indonesia \\ abyathoya@gmail.com
}

DOI: https://doi.org/10.21154/ sajiem.v2i1.44

\begin{abstract}
The purpose of writing this article is to examine the concept of improving the quality of Kaoru Ishikawa and its implementation in improving the quality of education. Quality according to Ishikawa is customer satisfaction and quality is not only product quality but also includes people, processes, and every aspect of the organization. The quality improvement effort made by Ishikawa is by implementing a Quality Control system. In this effort, Ishikawa recommends establishing a QC Circle and the use of basic quality tools, one of which is the Cause and Effect Diagram. This Ishikawa quality concept can be implemented in education, including: 1) Improving the Quality of Education Output through Quality Control; and 2) The basis for formulating a strategy to improve the quality of education based on cause and effect. The concept of Ishikawa quality improvement provides motivation for educational institutions to carry out good quality management, one of which is consistency in carrying out quality control through the formation of a QC Circle and the use of quality control tools, one of which is the Cause and Effect Diagram. Thus, educational institutions can improve their quality by knowing the root causes of the problems that occur and determining the appropriate quality improvement strategy.
\end{abstract}

Keywords: Education Quality Development, Quality of Kaoru Ishikawa, Quality Control, Quality Control Circle, Cause and Effect Diagram

\section{Pendahuluan}

Saat ini, mutu merupakan faktor utama di sebuah negara untuk meningkatkan daya saing. Para ilmuwan telah sampai pada kesimpulan bahwa dalam kondisi saat ini revolusi informasi, keunggulan kompetitif tidak ditentukan oleh ukuran negara, atau oleh sumber daya alamnya yang kaya, atau dengan modal finansial dalam jumlah yang signifikan, yang paling 
penting adalah tingkat pendidikan dan jumlah pengetahuan yang diakumulasikan oleh masyarakat. Selain itu, pengetahuan dengan cepat menjadi usang, pengetahuan baru menggantikannya, dan proses ini akan diulang tanpa akhir. Karena itu, orang perlu belajar sepanjang waktu hidup untuk memenuhi persyaratan zaman modern tersebut. ${ }^{1}$

Setiap orang maupun institusi manapun pasti mendambakan visi agar dirinya maupun isntitusinya memiliki kualitas atau mutu. Mutu dapat menjadikan diri seseorang maupun institusi dapat bertahan sekaligus menjadikan pemenang dalam setiap kompetisi kehidupan di era globalisasi saat ini. Sulit dan mungkin mahal untuk diwujudkan, karena mutu identik dengan segala sesuatu yang 'baik' dan 'sempurna'. Pernyataan ini bisa dikatakan tidak salah, meskipun juga kurang tepat. ${ }^{2}$

Berbagai pihak di segala bidang dan sektor apapun mau tidak mau harus siap menghadapi era globalisasi yang penuh dengan persaingan mutu. Kesiapan ini harus ditunjukkan dengan selalu meningkatkan kompetensi yang dimiliki jika tidak ingin tertinggal. Demikian halnya pada bidang atau sektor pendidikan di Indonesia. Peningkatan kualitas pendidikan baik secara kualitatif maupun kuantitatif secara kontinyu menjadi suatu keniscayaan bagi semua penyelenggara pendidikan, sehingga apa yang menjadi esensi pendidikan nasional sebagai wahana membangun watak dan moral generasi penerus bangsa dapat terlaksana dengan optimal. ${ }^{3}$

Untuk menjawab tantangan tersebut di atas, maka penerapan manajemen mutu terpadu (Total Quality Management) menjadi mutlak untuk dilaksanakan dalam lembaga pendidikan. Dengan penerapan manajemen mutu inilah, lembaga pendidikan mampu meningkatkan kualitas layanan pendidikannya dan mampu bersaing dengan lembaga pendidikan lainnya. Keberadaan TQM yang digunakan dalam penerapan di dunia bisnis menuai hasil yang sangat signifikan, sehingga TQM memiliki daya tarik tersendiri, untuk bisa diaplikasikan pada objek-objek kelembagaan atau organisasi yang lain, baik dalam bidang politik, sosial, termasuk dalam dunia pendidikan. Hal ini dalam rangka efektivitas dan hasil yang baik sebagai target yang diidam-idamkan. Manajemen Mutu Terpadu merupakan metodologi yang jika diterapkan secara tepat dapat membantu para pengelola atau penyelenggara pendidikan di lembaga pendidikan termasuk madrasah dalam mewujudkan penyelenggaraan pendidikan dan lulusan yang dapat memenuhi atau melebihi keinginan atau harapan para stakeholdernya. ${ }^{4}$

Semenjak lahirnya TQM ini, para praktisi pendidikan berbondong-bondong untuk mempelajari TQM dari berbagai guru mutu yang salah satunya adalah dari Kaoru Ishikawa. Ishikawa adalah orang yang telah memberikan pengaruh besar terhadap peningkatan mutu dalam bidang industry di Jepang. Ia adalah penggerak kualitas dengan memperkenalkan dan mengembangkan quality control pada perusahaan. Dedikasi Ishikawa untuk quality control adalah lebih dari ekpektasi, tetapi juga dilandasi dengan semangat keagamaan sebagiamana yang pernah ia kataka: "Jika setiap negara memainkan perannya dalam mempromosikan quality control, maka dunia akan menemukan kedamaian, dan rakyatnya akan bisa hidup bersama harmonis dan bahagia. Perusahaan yang tidak melakukan quality control tidak akan bertahan lama". ${ }^{5}$

Penyataan Ishikawa ini memberikan pesan bahwa di dalam mengelola organisasi termasuk di dalamnya organisasi pendidikan, harus menjalankan proses quality control. Hal ini

${ }^{1}$ Bakhyt Baitanayeva et al., "Problems Of Improving The Quality Of Education," E3S Web of Conferences 159 (2020): 1, https://doi.org/10.1051/e3sconf/202015909002.

${ }_{2}^{2}$ Muhammad Fathurrohman, "Pengembangan Budaya Religius Dalam Meningkatkan Mutu Pendidikan," Ta'allum: Jurnal Pendidikan Islam 4, no. 1 (2016): 21, https://doi.org/10.21274/taalum.2016.4.1.19-42.

${ }^{3}$ E. Mulyasa, Standar Kompetensi Dan Sertifikasi Guru (Bandung: PT. Remaja Rosdakarya, 2007), 17.

${ }^{4}$ Akmal Mundiri, "Strategi Lembaga Pendidikan Islam Dalam Membangun Branding Image," Pedagogik: Jurnal Pendidikan 3, no. 2 (2016): 62.

${ }^{5}$ Marc Balbirnie, "Proffesor Kaoru Ishikawa: A Man In Search Of Harmony," IASSC Lean Six Sigma Green Belt, 1989, 1 . 
penting dilakukan untuk menjaga kualitas dan menjaga eksistensi organisasi dengan tujuan akhir yaitu memenuhi kepuasan pelanggan. Namun demikian, konsep mutu Ishikawa tersebut lebih banyak dikembangkan pada sector perusahaan (corporate), walaupun ia juga termasuk praktisi pendidikan di University of Tokyo sehingga sangat mungkin konsepnya tersebut dapat diterapkan pada dunia pendidikan. Untuk itulah perlu pemahaman yang komprehendif terhadap konsepnya ini agar dapat diimplementasikan dengan baik.

Berangkat dari latar belakang tersebut, artikel ini akan mengkaji tentang konsep peningkatan mutu Kaoru Ishikawa dan implementasinya pada peningkatan mutu pendidikan. Dengan demikian, akan diperoleh gambaran yang komprehensif mengenai konsepnya ini dan bentuk pengimplementasiannya di dunia pendidikan dalam rangka peningkatan mutunya.

\section{Metode Penelitian}

Artikel ini ditulis dengan pendekatan deskriptif kualitatif berupa kajian pustaka (library research). Data dikumpulkan dengan menggunakan teknik dokumentasi terhadap berbagai literatur terkait dengan konsep mutu menurut Kaoru Ishikawa dan implementasinya terhadap pengembangan mutu pendidikan, termasuk berbagai hasil penelitian yang relevan dengan fokus kajian. Sementara itu, teknik analisis yang digunakan adalah analisis isi (content analysis), dengan demikian akan didapatkan kajian yang dapat disajikan secara komprehensif dan sistematis terkait dengan model pengembangan mutu pendidikan.

\section{Temuan dan Pembahasan}

\section{Biografi Singkat Kaoru Ishikawa}

Kaoru Ishikawa lahir pada tanggal 13 Juli 1915 sebagai anak tertua dari delapan bersaudara Ichiro Ishikawa, presiden pertama Federation of Economic Organization of Japan. Grup ini terdiri dari pemimpin puncak komunitas bisnis antar negara. Sebagai salah satu pemimpin terkemuka, Ichiro Ishikawa menginginkan Jepang maju sebagai negara industri dan tidak jatuh kembali ke ekonomi pertanian lama. Untuk mencapai tujuan tersebut, Jepang dihadapkan pada banyak hambatan. Kualitas buruk adalah satu hambatan utamanya. Tidak seorang pun ingin membeli kembali barang-barang berkualitas rendah buatan Jepang pada saat itu. Untuk sebuah negara menjadi kekurangan bahan baku, ketidakmampuan untuk melakukan ekspor produk berarti juga ketidakmampuan untuk menghasilkan pendapatan, dan karenanya menjadi tidak mampu untuk membeli bahan baku yang dibutuhkan untuk menciptakan sekaligus mengembangkan industri secara berkelanjutan. Jadi, revolusi dalam kualitas produk menjadi hal yang sangat penting.

Setelah lulus dari jurusan Kimia Terapan di Imperial University of Tokyo pada tahun 1939, Kaoru Ishikawa menjabat sebagai tenaga teknis angkatan laut selama dua tahun dan kemudian bergabung dengan Nissan Liquid Fuel Company. Di sana, ia bekerja sebagai insinyur produksi hingga 1947. Selama periode ini, Ishikawa memiliki banyak peluang untuk belajar dari pengalaman praktiknya. ${ }^{6}$

Pada tahun 1947, Ishikawa kembali ke University of Tokyo untuk melanjutkan studinya, tetapi dia tidak terlibat dengan kontrol kualitas secara langsung. Untuk meningkatkan kualitas analisis studi eksperimentalnya, Ishikawa mulai belajar metode statistik pada tahun 1948. Dia mendekati Union of Japanese Scientists and Engineers (JUSE) pada tahun 1949 untuk mencari bimbingan dan informasi umum tentang metode statistik yang dirancang secara efektif oleh Kenichi Koyanagi, direktur pelaksana senior JUSE, sebagai penasihat akademik untuk quality control dan metode statistik. Ishikawa mengambil beberapa langkah termasuk membuat modul wajib untuk mahasiswa Teknik semester pertama di University of Tokyo, yang ia sebut "How to Use Experimental

\footnotetext{
${ }^{6}$ Yoshio Kondo, "Kaoru Ishikawa: What He Thought and Achieved, a Basis for Further Research," Quality Management Journal 1, no. 4 (July 25, 1994): 87, https://doi.org/10.1080/10686967.1994.11918666.
} 
Data". Dari sinilah ia mulai terjun ke bidang quality control dan pekerjaannya di bidang itu tumbuh secara eksponensial.

Ishikawa sering mengatakan bahwa tidak ada gunanya hanya membaca literatur saja dan ada banyak masalah yang dapat dipecahkan dalam proses manufaktur dan jasa. Dia juga berkata, "perluas sudut pandang dan terus melihat negara-negara luar". Dia lebih suka praktik daripada logika. Juran menggambarkan Ishikawa sebagai "praktisi terkenal dunia" dan menulis bahwa ia mencapai banyak hal dengan memanfaatkan bakat alaminya. Dia rupanya memiliki keahlian khusus dalam memobilisasi banyak orang sebagai penyebab ia berkontribusi kepada masyarakat. Dia bisa melakukannya karena karyanya selalu didasarkan pada penegasan dan analisis fakta. Soma menambahkan, Ishikawa adalah pribadi yang kuat untuk melibatkan banyak orang dari dalam dan di luar bidang Quality Control (QC) dan untuk mengembangkan kegiatan QC secara nasional dan di seluruh dunia. ${ }^{7}$

Ishikawa terlibat dalam standarisasi internasional Jepang selama beberapa dekade. Setelah Deming dan Juran mengunjungi Jepang, Ishikawa memulai "Company-wide Quality Control" selama periode 1955-6o dan memperkenalkan konsep Quality Circle pada tahun 1962. Dia menulis dua buku tentang Quality Circle (QC Circle Koryo and How to Operate QC Circle Activities). Quality Circle adalah pendekatan bottom-up untuk menanamkan kualitas ke dalam suatu produk atau jasa. Ishikawa disebut sebagai "father of quality circle" untuk inisiatifnya tersebut.

Ishikawa menerima berbagai penghargaan di antaranya American Society for Quality (ASQ)'s Eugene L. Grant Award pada tahun 1972, Japanese government's Blue Ribbon Medal pada tahun 1977, Second Order of the Sacred Treasure pada tahun 1988, dan Walter A. Shewhart Medal pada tahun 1982. Pada tahun 1993, ASQ mendirikan Ishikawa Medal sebagai simbol untuk penghargaan individu atau kepemimpinan tim dalam meningkatkan sisi kualitas manusia, dan memanggilnya "perintis terkemuka dalam pencapaian rasa hormat terhadap kemanusiaan dalam disiplin kualitas".

\section{Mutu Menurut Kaoru Ishikawa}

Ishikawa adalah penggerak utama kualitas di Jepang. Dia memprakarsai banyak program di Jepang dan sebagian besar dikembangkan dari konsep W. Edwards Deming dan Joseph M. Juran menjadi pendekatan khas Jepang untuk peningkatan kualitas. Goetsch dan Davis ${ }^{9}$ menggambarkan dua pilar utama Ishikawa kualitas sebagai berikut: a) kualitas dan kepuasan pelanggan adalah hal yang sama, dan b) kualitas adalah konsep luas yang melampaui tidak hanya kualitas produk akan tetapi termasuk juga kualitas orang, proses, dan setiap aspek dalam organisasi. Konsep umum kualitas Ishikawa pada dasarnya adalah berfokus pada pelanggan.

Terdapat beberapa konsep kualitas yang ditekankan oleh Ishikawa yaitu enam prinsip kualitas dan kualitas melalui kepemimpinan. Enam prinsipnya menjadi fundamental dalam dirinya mengajar dan membentuk paradigma kualitas di Jepang. Enam prinsip kualitas tersebut adalah: ${ }^{10}$ a) Semua karyawan harus memahami dengan jelas tujuan dan alasan bisnis di balik pengenalan dan promosi quality control seluruh perusahaan; b) Berbagai fitur sistem mutu seharusnya diklarifikasi di semua tingkatan organisasi dan dikomunikasikan sedemikian rupa sehingga orang mempunyai rasa percaya diri pada fiturfitur ini; c) Siklus perbaikan berkelanjutan harus terus diterapkan di seluruh perusahaan setidaknya selama tiga hingga lima tahun ke depan untuk mengembangkan standarisari

\footnotetext{
${ }^{7}$ Balbirnie, "Proffesor Kaoru Ishikawa: A Man In Search Of Harmony," 2.

${ }^{8}$ M. Best and D. Neuhauser, "Kaoru Ishikawa: From Fishbones To World Peace.," Quality E Safety in Health Care 17, no. 2 (2008): 150, https://doi.org/10.1136/qshc.2007.025692.

${ }^{9}$ David L. Goetsch and Stanley Davis, Quality Management for Organizational Excellence: Introduction to Total Quality (Pearson Education Limited, 2014).

${ }^{10}$ Greg Watson, “The Legacy Of Ishikawa," Quality Progress 37, no. 4 (2004): 55.
} 
pekerjaan. Keduanya, statistik kontrol kualitas dan analisis proses seharusnya digunakan, dan kontrol untuk pemasok harus dikembangkan dan diterapkan secara efektif; d) Perusahaan harus mendefinisikan rencana kualitas jangka panjang dan melaksanakannya secara sistematis; e) Dinding antar departemen harus dipecah, dan manajemen lintas fungsional harus diterapkan; dan f) Setiap orang harus bertindak dengan percaya diri, dan percaya bahwa pekerjaannya akan membuahkan hasil. Ishikawa memadukan ide dan prinsip ini menjadi sebuah sistem berpikir kualitas yang didefinisikan secara holistik untuk mencapai peningkatan kinerja bisnis.

Enam prinsip yang dijelaskan oleh Ishikawa tersebut memberikan pengertian bahwa terdapat empat area fokus utama dari pendekatan Jepang untuk mempengaruhi kualitas yaitu melalui kepemimpinan. Menurutnya, empat fokus utama ini masing-masing menjadi sangat penting dalam kinerjanya membangun kualitas. Pertama, pasar berkualitas. Ishikawa tahu bahwa kualitas bisa memberikan kontribusi yang kuat untuk persaingan bisnis ketika sebuah organisasi mau belajar untuk mengevaluasi produk dan jasa sesuai dengan standar yang diterima pelanggan. Setelah persyaratan pelanggan dapat dipenuhi, rantai proses internal itu akan memberikan nilai lebih kepada pasar. Pendekatan seluruh perusahaan untuk pekerjaan yang berkualitas membutuhkan kepemimpinan langsung oleh manajemen puncak.

Ishikawa menekankan perspektif strategis "quality first" sebagai prinsip dasar untuk filosofi operasi setiap organisasi. Dia memfokuskan pada definisi kualitas dari pandangan pelanggan daripada kinerja internal perusahaan. Penekanannya pada bisnis pelanggan saat itu menjadi unik karena sebagian besar upaya kualitas difokuskan pada kontrol kualitas industri dan aplikasi internal untuk manufaktur. Ishikawa juga menekankan bahwa pelanggan adalah satu-satunya alasan bisnis kami.

Kedua, keterlibatan pekerja. Ishikawa percaya semua pekerja harus terlibat dalam peningkatan kualitas melalui tim untuk meningkatkan kemampuan individu pekerja dan meningkatkan proses kerja. Semua bekerja harus menyertakan tindakan korektif dan preventif untuk mengungkap dan menyelesaikan masalah di hilir dari titik keterlibatan pelanggan. Untuk dapat melakukan tugas-tugas ini, pekerja harus dilatih dengan alat dasar pemecah masalah dan metode kontrol dan bekerja dalam tim lintas fungsional untuk menyelesaikan masalah pada kelompok kerja. Ishikawa menekankan mengajar pekerja tentang alat kualitas dasar untuk melengkapi mereka dengan kemampuan untuk mengatur diri sendiri di lingkungan tempat mereka bekerja. Hal ini mendukung peningkatan kualitas dan produktivitas dalam manajemen.

Ketiga, kualitas dimulai dan diakhiri dengan pendidikan. Untuk memahami arti sebenarnya dari ajaran Ishikawa tentang pendidikan, penting untuk mengetahui caranya bagaimana ia membedakan antara pendidikan dan pelatihan. Ia percaya bahwa pelatihan meningkatkan keterampilan dan kompetensi, dan pendidikan membangun karakter seseorang dan mengembangkan tingkat pemahaman yang lebih dalam. Ishikawa menyatukan idenya tersebut menjadi perspektif kualitas yang sistematis yang meresap hingga hari ini: "Sembilan puluh persen dari semua masalah bisa diselesaikan dengan menggunakan teknik stratifikasi data, histogram dan control charts (diagram control). Di antara penyebab ketidaksesuaian, hanya seperlima atau bahkan kurang yang dikaitkan dengan kemampuan para pekerja”.

Pendidikan mempercepat pengalaman hidup dan memungkinkan orang untuk memahami kebenaran. Ishikawa mengajarkan bahwa langkah selanjutnya dalam setiap proses kerja adalah pelanggan, siapa yang layak mendapat perhatian, dan proses seharusnya dianalisis untuk mengungkap fakta dan data tentang kinerja dari sudut pandang pelanggan. Pendidikan menciptakan pemahaman dan keraguan, karena orang yang ragu akan memiliki keyakinan bahwa mereka mampu untuk menemukan kebenaran. Jika anggota manajemen tim memberikan pendidikan untuk pekerja mereka, pekerjaan secara kolektif dapat menentukan cara terbaik untuk mengelola proses kerja dan 
hasilnya sesuai dengan yang dibutuhkan oleh pelanggan. Pendidikan untuk pekerja tentang alat dan metode dasar kualitas adalah warisan lain dari Ishikawa diterima sebagai praktik kerja yang standar.

Keempat, komitmen pribadi tanpa pamrih. Pidato Juran untuk Ishikawa: Ada banyak yang bisa dipelajari dari cara Ishikawa berhasil mencapai begitu banyak hal selama seumur hidupnya. Dalam pengamatan saya, dia melakukannya dengan menerapkan karunia alaminya dengan cara yang patut dicontoh. Dia dedikasikan dirinya untuk melayani masyarakat daripada melayani dirinya sendiri. Sikapnya sederhana, dan selalu bekerja sama dengan orang lain. Dia benar-benar tulus, dan hasilnya dapat dipercaya sepenuhnya.

\section{Sistem Quality Control Kaoru Ishikawa}

Prestasi terbesar Kaoru Ishikawa adalah dalam penyebaran dan pengembangan quality control. Ishikawa menyatakan, "Saya yakin perdamaian dan kemakmuran dunia perlu kontrol kualitas. Inilah mengapa kontrol kualitas harus dilakukan, diajarkan dan menyebar ke seluruh dunia"." Quality control Jepang adalah revolusi pemikiran dalam manajemen. Ini adalah pendekatan yang mewakili cara berpikir baru tentang manajemen.

Ishikawa mendefinisikan quality control sebagai berikut: "quality control adalah untuk mengembangkan, merancang, memproduksi dan melayani produk berkualitas yang paling ekonomis, paling berguna, dan selalu memuaskan bagi konsumen". ${ }^{22}$ Untuk mencapai tujuan ini, setiap orang di perusahaan harus berpartisipasi dan mempromosikan kontrol kualitas, termasuk eksekutif puncak, semua divisi dalam perusahaan, dan semua karyawan.

Ishikawa menguraikan sejumlah petunjuk dalam menerapkan quality control: ${ }^{13}$

a. Quality control dilibatkan untuk memproduksi produk dengan kualitas yang dapat memenuhi persyaratan konsumen. Harus diingat bahwa persyaratan konsumen berubah dari tahun ke tahun dan umumnya bahkan ketika standar industri dimodifikasi, mereka tidak dapat mengimbangi persyaratan konsumen. Untuk itulah diperlukan quality control dalam melakukan proses poduksi.

b. Penekanan pada orientasi konsumen. Produsen harus berpikir bahwa mereka melakukan kebaikan kepada konsumen dengan menjual produk mereka. Kebutuhan konsumen haruslah menjadi perhatian utama. Dalam istilah praktis, pabrikan harus mempelajari opini dan persyaratan konsumen, dan memperhitungkannya ketika mereka mendesain, memproduksi, dan menjual produk mereka. Ketika mengembangkan produk baru, produsen harus mengantisipasi persyaratan dan kebutuhan konsumen. Ada pepatah yang mengatakan bahwa konsumen adalah raja. Hak memilih produk ada pada konsumen.

c. Diartikan secara sempit, kualitas berarti kualitas produk. Diartikan secara luas, kualitas berarti kualitas pekerjaan, kualitas layanan, kualitas informasi, kualitas proses, kualitas divisi, kualitas orang, termasuk pekerja, insinyur, manajer, dan eksekutif, kualitas sistem, kualitas perusahaan, kualitas tujuan, dan lain-lain. Untuk mengontrol kualitas dalam setiap manifestasinya adalah pendekatan dasar kami.

d. Tidak peduli seberapa tinggi kualitasnya, jika produk itu terlalu mahal, ia tidak bisa memberikan kepuasan kepada pelanggan. Dengan kata lain, seseorang tidak dapat mendefinisikan kualitas tanpa mempertimbangkan harga. Ini penting dalam perencanaan dan perancangan kualitas. Tidak ada quality control yang mengabaikan harga, laba, dan kontrol biaya. Pasokan produk yang tidak memadai sesuai dengan

\footnotetext{
${ }^{11}$ Best and Neuhauser, "Kaoru Ishikawa: From Fishbones To World Peace.," 151.

${ }^{12}$ Kaoru Ishikawa, What Is Total Quality Control? The Japanese Way (Englewood Cliffs: Prentice-Hall, 1985), 45 .

${ }^{13}$ Ishikawa, 45-46.
} 
yang diminati akan membuat pelanggan tidak nyaman. Pasokan yang berlebihan akan menjadi pemborosan tenaga kerja, bahan baku, dan energi. Kontrol biaya dan quality control adalah dua sisi dari mata uang yang sama. Untuk melakukan kontrol biaya yang efektif, quality control yang efektif harus diterapkan.

Ketika semua divisi dan semua karyawan perusahaan berpartisipasi dalam total quality control, mereka harus terlibat dalam quality control dalam arti yang lebih luas, termasuk kontrol biaya dan kontrol kuantitas. Kalau tidak, quality control, bahkan dalam arti sempitnya, tidak dapat dicapai. Ini adalah alasan mengapa total quality control juga disebut "integrated quality control", "full participation quality control", dan "control of management quality". ${ }^{14}$

Quality control dapat dilakukan dengan beberapa langkah. Ishikawa menyebutkan bahwa konsep Taylor dapat digunakan untuk menggambarkan kontrol dengan plan-do-see nya. Ishikawa mengembangkan konsep tersebut menjadi plan-do-check-action (PDCA). Inilah yang disebutnya Quality Circle dan harus dibuat untuk bergerak ke arah yang benar. Kemudian Ishikawa mengembangkan lebih lanjut dengan mendefinisikan ulang lingkaran ini dengan membaginya menjadi enam kategori. Kontrol diatur berdasarkan enam kategori ini, yang telah terbukti berhasil. Keenam langkah tersebut adalah sebagai berikut:
a. Tentukan tujuan dan sasaran
b. Tentukan metode untuk mencapai tujuan
c. Terlibat dalam pendidikan dan pelatihan
d. Melaksanakan pekerjaan
e. Periksa efek implementasi
f. Ambil tindakan yang tepat. ${ }^{15}$

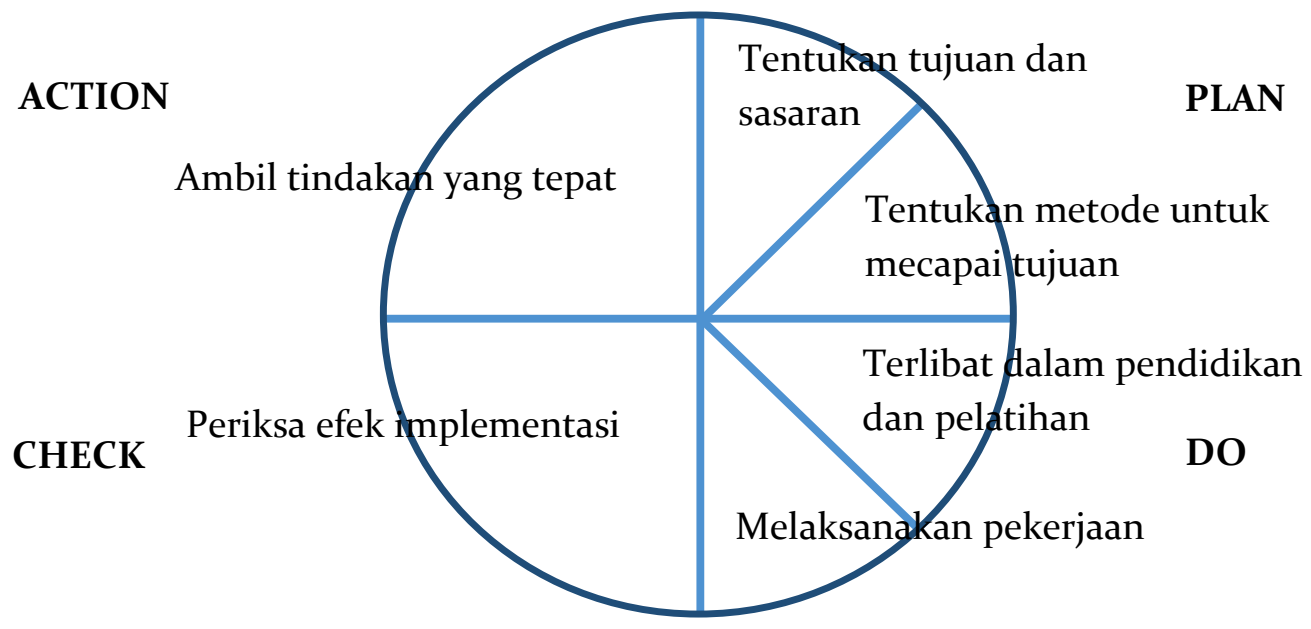

Gambar 1. Quality Circle

Dalam implementasi quality control, Ishikawa menganjurkan pembentukan "Quality Control Circel" guna mendidik dan mempromosikan quality control untuk pekerja di tempat mereka bekerja, serta menggunakan alat quality control seperti cause and effect diagram sebagai upaya untuk mewujudkannya Total Quality Control.

\section{a. Quality Control Circle}

Pada tahun 1950-an, Ishikawa terlibat dengan program pelatihan yang disebut "workshop QC study groups" (lokakarya kelompok studi QC). Kemudian kelompok ini diubah namanya menjadi aktivitas "QC (Quality Control) Circle" (lingkaran kendali

\footnotetext{
${ }^{14}$ Ishikawa, 45-47.

${ }^{15}$ Ishikawa, 59.
} 
mutu) pada bulan April tahun 1962, dan metode ini menyebar dengan cepat dari di sana, menjadi salah satu alat quality control utama yang membantu pengembangan industri manufaktur Jepang pada tahun 1960-an sampai dengan 1970-an. Ishikawa dalam karyanya menguraikan bahwa awalnya ia hanya percaya QC Circle hanya dapat bekerja dalam konteks Jepang dengan sifat budaya tenaga kerja, tetapi kemudian ia menyimpulkan bahwa pendapatnya itu tidak benar, menurutnya QC Circle berlaku dalam semua konteks karena kesamaan yang dimiliki oleh semua umat manusia. Pendekatan ini sebenarnya pernah dicoba di Amerika pada tahun 1970-an dan hasilnya mengecewakan. Ini tidak diragukan lagi karena fakta menunjukkan bahwa Japanese Circle diintegrasikan selama satu dekade, aktivitas proses peningkatan dilakukan di seluruh perusahaan, sementara perusahaan Amerika mengimplementasikannya dalam lingkaran itu sendiri.

Konsep QC Circle pada dasarnya cukup sederhana. Dalam bukunya Introduction to Quality Control, Ishikawa menggambarkan QC Circle sebagai "kelompok kecil orang dari kelompok kerja yang sama yang melakukan kegiatan kontrol kualitas secara sukarela. Kelompok-kelompok kecil ini melakukan pengembangan diri dan pengembangan yang saling menguntungkan sebagai bagian dari kegiatan Total Quality Control (TQC) seluruh perusahaan dan menggunakan alat QC untuk mengontrol dan peningkatan kerja secara terus menerus, dengan semua orang ambil bagian di dalamnya" ${ }^{16}$ Kegiatan QC Circle bertujuan untuk memunculkan dan mengembangkan kemampuan potensial anggota. ${ }^{17}$

Partisipasi sukarela anggota adalah aspek penting dari QC Circle ini. Ia juga menguraikan filosofi kerja: "Tempat kerja yang ceria yang membuat hidup berharga dan di mana rasa kemanusiaan dihormati". Sentimen utopis ini membawa kita keluar dari gagasan sederhana bahwa produktivitas dan output seharusnya satu-satunya ukuran proses atau perusahaan yang efektif, dan meminta kita untuk mempertimbangkan komponen manusia dalam organisasi.

Maslow's Hierarchy of Needs yang diterapkan pada manajemen organisasi berpendapat bahwa pelibatan ketenagakerjaan adalah inti dari pengembangan individu dan organisasi. Ishikawa menggemakan sentimen ini dengan mempertimbangkan gemba, istilah bagi orang Jepang untuk tempat kerja, sebagai struktur sosiologis.

QC Circle didesain memotong semua area peningkatan kualitas termasuk integrasi jaminan kualitas dalam pengembangan produk baru. Dengan cara ini QC Circle berpotensi mewakili mayoritas poin dialog untuk diterapkan Total Quality Control (TQC) atau Company-Wide Quality Control (CWQC).$^{18}$ Berikut gambarnya:

\footnotetext{
${ }^{16}$ Kaoru Ishikawa, Introduction to Quality Control, 3rd ed. (3A Corporation, 1990).

${ }^{17}$ Tatsuo Sugimoto, "Father of the QC Circle : Prof. Kaoru Ishikawa," Kaoru Ishikawa, The Man and Quality Control, no. 319 (2015): 1

${ }^{18}$ Balbirnie, "Proffesor Kaoru Ishikawa: A Man In Search Of Harmony," 4.
} 


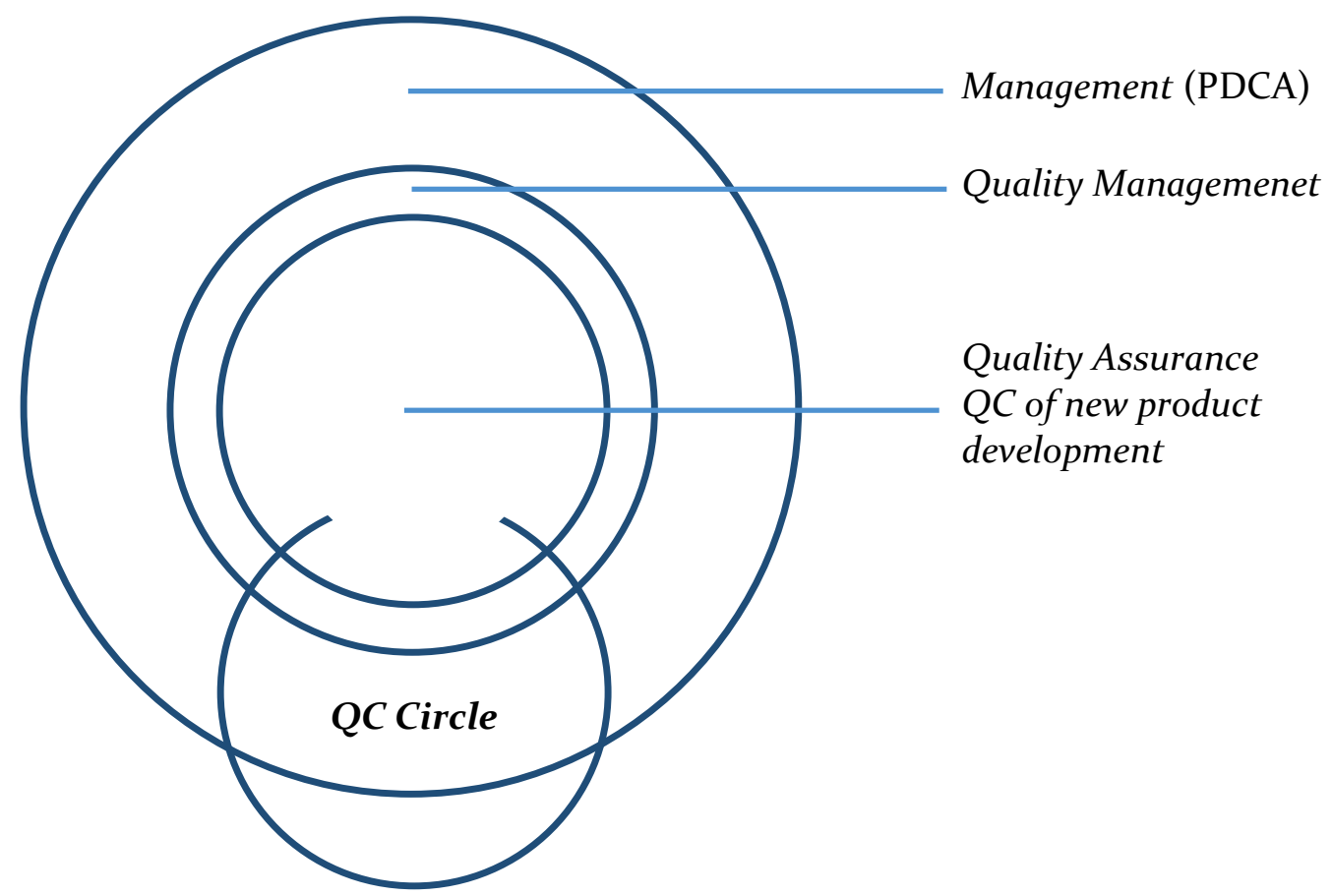

Gambar 2. Ishikawa CWQC ${ }^{19}$

Lingkaran pusat yang merupakan intisari quality control mengandung jaminan mutu dalam arti sempit, yang berarti melakukan quality control dengan baik bagi produk-produk baru perusahaan. Lingkaran kedua menggambarkan quality control dalam arti luas di antaranya meliputi mutu penjualan, mutu tenaga penjualan, pekerjaan kantor yang efisien dan penanganan subkontraktor yang lebih efektif. Sedangkan pada lingkaran ketiga pengertian terhadap quality control menjadi lebih luas lagi. quality control pada lingkaran ketiga dilakukan terhadap semua tahap pekerjaan dan dilaksanakan dengan lebih efektif dengan menggunakan siklus PDCA (plan, do, check, dan action). Sementara itu, QC Circle sebagai suatu lingkaran yang memotong lingkaran-lingkaran lainnya. Kegiatan QC Circle adalah bagian dari kegiatan-kegiatan quality control perusahaan secara menyeluruh. ${ }^{20}$

b. Cause and Effect Diagram sebagai alat QC

Cause and Effect Diagram pertama kali dikembangkan oleh Kaoru Ishikawa pada musim panas tahun 1943, pada waktu itu ia menjelaskan kepada beberapa insinyur di pabrik Kawasaki Steel Works, fakta bahwa berbagai faktor dapat disortir dan dihubungkan sedemikian rupa. Dalam hal ini, Cause and Effect Diagram adalah metode QC yang berasal dari Jepang dan kemudian mulai digunakan secara luas di seluruh industri di Jepang dan menjadi sangat diperlukan untuk melakukan quality control. Cause and Effect Diagram digunakan tidak hanya untuk masalah QC akan tetapi dapat diterapkan untuk solusi dari masalah apa pun. Penggunaan Cause and Effect Diagram yang efektif adalah langkah utama untuk mempromosikan kegiatan QC. ${ }^{21}$

Cause and Effect Diagram telah dibahas dalam kaitannya dengan kualitas. Tetapi karena diagram seperti ini menggambarkan hubungan antara sebab dan akibat secara rasional, maka dapat digunakan dalam situasi apa pun. Cause and Effect Diagram yang ditunjukkan pada Gambar 3. dibuat untuk meningkatkan hubungan timbal balik antara QC Circle di perusahaan yang berbeda. Dengan cara ini, Cause and

\footnotetext{
${ }^{19}$ Ishikawa, What Is Total Quality Control? The Japanese Way, 59.

${ }^{20}$ Ishikawa, Introduction to Quality Control, 45.

${ }^{21}$ Kaoru Ishikawa, Guide to Quality Control (Tokyo: Asian Productivity Organization, 1976), 27-28.
} 
Effect Diagram dapat dibuat tidak hanya untuk masalah kualitas tetapi untuk kuantitas, jumlah material dan bahkan untuk keselamatan, kehadiran di tempat kerja, atau segala jenis masalah personal. Tujuannya adalah untuk mendapatkan hasil; karena tindakan harus diambil terhadap penyebabnya, jika kita tidak tahu hubungan antara sebab dan akibat dari suatu masalah, maka tidak akan dapat mengambil tindakan apa pun untuk menyelesaikannya. Cause and Effect Diagram menunjukkan penyebab yang paling jelas sehingga dapat diambil tindakan dengan cepat. ${ }^{22}$

Cause and Effect Diagram atau Ishikawa's Fishbone Diagram adalah dianggap sebagai salah satu dari tujuh alat kualitas dasar selain Pareto Diagram, Work Sheet, Histogram, Scatter Diagram, Control Chart dan Graphs ${ }^{23}$. Namun yang perlu diperhatikan tentang Cause and Effect Diagram bahwa diagram itu adalah satu-satunya dari tujuh alat kualitas dasar yang tidak didasarkan pada statistik. Hal ini dikarenakan pemecahan masalah melalui pemahaman tentang interaksi kausal beberapa input dan konteks, yang bertentangan dengan menafsirkan masalah dan solusi potensial murni melalui analisis data statistik. Karena alasan inilah diagram Ishikawa memiliki cakupan luas untuk berbagai kegunaan yang potensial. Sedangkan Statitical Process Control seperti Pareto Diagram, Work Sheet, Histogram, Scatter Diagram, Control Chart dan Graphs akan melakukan banyak hal untuk menggambarkan kondisi proses saat ini. ${ }^{24}$

Diagram Ishikawa dirancang dalam konteks praktis dengan fokus pada pemahaman yang lebih dalam tentang "mengapa-nya" dalam proses. Diagram Ishikawa dapat digunakan untuk memecah secara efektif masalah ke dalam matriks hubungan sebab akibat. Diagram tersebut digunakan untuk mengidentifikasi penyebab setelah difokuskan definisi masalah dalam tim atau QC Circle, beberapa individu dapat memberikan saran dan pendapat tentang faktor kausal apa saja yang paling berpengaruh yang menyebabkan efek atau masalah.

Cause and Effect Diagram digunakan untuk mengeksplorasi input (SDM, proses, alat, material, lingkungan dan manajemen) yang bisa jelaskan hasilnya. Diagram tersebut digunakan untuk mendorong karyawan berpartisipasi dan meningkatkan pemahaman proses dan dapat digunakan untuk mengidentifikasi akar penyebab masalah atau cacat, identifikasi kemungkinan variasi penyebab masalah dan identifikasi area utama untuk pengumpulan data. Hal ini adalah cara untuk membuat daftar berbagai kemungkinan penyebab dan peluang untuk perbaikan. Proses ini harus terjadi atau dilakukan dalam format diskusi egaliter terbuka, untuk menarik ide dan pendapat dari semua orang. Ishikawa bersikeras bahwa komunikasi kelompok secara terbuka ini sangat penting untuk membuat diagram dengan tepat. Pentingnya diagram ini bukan hanya digunakan sebagai cara visual untuk kelompok kerja, akan tetapi lebih dari itu untuk memahami variasi penyebab dalam proses mereka bekerja. ${ }^{25}$

\footnotetext{
${ }^{22}$ Ishikawa, 26.

${ }^{23}$ Keterangan lebih lanjut tentang 6 (enam) alat kualitas tersebut dapat dilihat di Ishikawa, Guide to Quality Control.

${ }^{24}$ Goetsch and Davis, Quality Management for Organizational Excellence: Introduction to Total Quality.

${ }^{25}$ Best and Neuhauser, "Kaoru Ishikawa: From Fishbones To World Peace.," 150.
} 


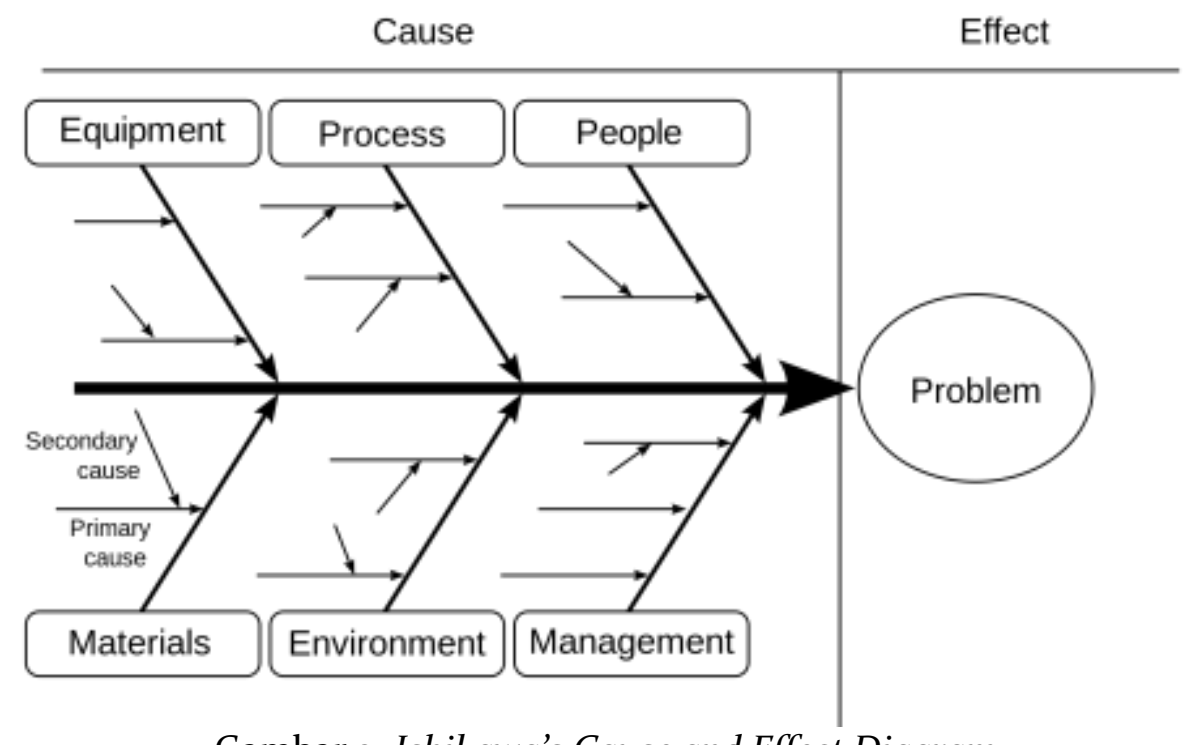

Gambar 3. Ishikawa's Cause and Effect Diagram

Panah horizontal mengarah ke kanan menunjukkan efek akhir atau output problem. Berbagai panah kemudian ditarik secara diagonal dari atas atau bawah menunjuk ke arah garis tengah. Akan ada enam panah (tiga di atas dan tiga di bawah) untuk menunjukkan SDM, proses, alat, material, lingkungan dan manajemen.

Panah grup kausal kemudian akan memiliki panah yang lebih kecil yang menunjuk ke arah panah kausal. Ini adalah tata letak klasik untuk diagram Ishikawa untuk menganalisis masalah proses manufaktur, tetapi bisa diubah untuk mengakomodasi segala jenis analisis dan konteks yang diinginkan. Yang unik dari diagram ini adalah diagram ini merupakan sistem analisis fraktal. Fraktal adalah struktur atau desain yang memiliki pola serupa terjadi pada skala perspektif yang berbeda. Secara teoritis, ini memungkinkan analisis meluas tanpa batas ke segala arah. ${ }^{26}$

\section{Implementasi Konsep Mutu Kaoru Ishikawa untuk Peningkatan Mutu Pendidikan}

Konsep mutu yang digagas Kaoru Ishikawa ini dapat diimplementasikan ke dalam dunia pendidikan setidaknya antara lain untuk: a) Peningkatan mutu output pendidikan melalui quality control; dan b) Dasar penyusunan strategi peningkatan mutu pendidikan berbasis cause and effect. Implementasi ini didasarkan pada kajian penulis terhadap beberapa artikel yang terkait dengan fokus pembahasan.

\section{a. Peningkatan Mutu Output Pendidikan melalui Quality Control}

Mutu pendidikan terdiri dari dua kata yakni mutu dan pendidikan. Dalam bahasa Inggris "quality” artinya mutu, kualitas. Dalam Kamus Besar Bahasa Indonesia "mutu" adalah (ukuran) baik buruk suatu benda, taraf atau derajat (kepandaian, kecerdasan). ${ }^{27}$ Secara istilah mutu adalah tingkat kualitas yang telah memenuhi atau bahkan dapat melebihi standar yang telah ditetapkan.

Berdasarkan Undang Undang Sisdiknas No. 20 Tahun 2003 pendidikan adalah usaha yang terencana untuk mewujudkan suasana belajar dan proses pembelajaran agar peserta didik secara aktif mengembangkan potensi diri agar memiliki kekuatan spiritual keagamaan, pengendalian diri, kepribadian, kecerdasan, akhlak mulia, serta skill yang diperlukan dirinya, masyarakat, bangsa dan negara. ${ }^{28}$

\footnotetext{
${ }^{26}$ Balbirnie, "Proffesor Kaoru Ishikawa: A Man In Search Of Harmony," 3.

${ }^{27}$ Lukman Ali, Kamus Besar Bahasa Indonesia (Jakarta: Balai Pustaka, 1995), 677.

${ }_{28}$ Presiden Republik Indonesia, "Undang-Undang Republik Indonesia Nomor 20 Tahun 2003 Tentang
} Sistem Pendidikan Nasional” (Jakarta, 2003) 
Menurut Hoy, Jardine and Wood menjelaskan bahwa mutu pendidikan adalah evaluasi proses pendidikan yang meningkatkan kebutuhan untuk mencapai dan proses pengembangan bakat para pelanggan (peserta didik), dan pada saat yang sama memenuhi standar akuntabilitas yang ditetapkan oleh klien (stakeholder) yang membayar untuk proses atau output dari proses pendidikan. ${ }^{29}$

Beeby menyebutkan bahwa mutu pendidikan dari tiga perspektif yaitu: perspektif ekonomi, sosiologi dan perspektif pendidikan. Dalam perspektif ekonomi, pendidikan itu bermutu jika memiliki kontribusi terhadap pertumbuhan ekonomi. Lulusan langsung memasuki dunia kerja dan mampu mendorong percepatan pertumbuhan ekonomi. Secara sosiologi, pendidikan bermutu jika pendidikan itu dapat memberi manfaat bagi masyarakat sedangkan pada perspektif pendidikan sendiri adalah dilihat dari aspek proses belajar mengajar dan aspek kemampuan lulusan memecahkan masalah dan berpikir kritis. Mutu Pendidikan merupakan kesesuaian antara kebutuhan pihak yang berkepentingan atau stakeholders baik internal (peserta didik, pendidik, kepala sekolah dan tenaga kependidikan lainnya) maupun eksternal (calon peserta didik, orang tua, masyarakat, pemerintah, dunia usaha dan industri), dengan layanan yang diberikan oleh pengelola pendidikan. ${ }^{30}$

Jadi dapat disimpulkan bahwa mutu pendidikan adalah tingkat kualitas pengelolaan pendidikan secara efektif dan efisien untuk mewujudkan suasana belajar dan proses pembelajaran agar peserta didik secara aktif mengembangkan potensi diri sehingga menghasilkan keluaran atau output yakni lulusan yang kompeten.

Pendidikan yang bermutu adalah pendidikan yang dapat menghasilkan keluaran, baik pelayanan, dan lulusan yang sesuai dengan kebutuhan atau harapan pelanggan (pasar)nya. Mutu dalam konteks pendidikan, berkaitan dengan upaya memberikan pelayanan yang paripurna dan memuaskan bagi para pemakai jasa pendidikan. Dalam sistem penyelenggaraan pendidikan, aspek mutu (quality) juga akan selalu berkaitan dengan bagaimana input peserta didik, proses penyelenggaraan pendidikan dengan fokus layanan peserta didik, sampai bagaimana output yang dihasilkan. Maka dari itu, mutu dalam pendidikan dapat saja disebutkan mengutamakan pelajar atau program perbaikan sekolah yang mungkin dilakukan secara lebih kreatif dan konstruktif.. ${ }^{31}$ Mutu dalam pendidikan memang dititik tekankan pada pelajar dan proses yang ada di dalamnya. Tanpa adanya proses yang baik, maka sekolah yang bermutu juga akan mustahil untuk dicapai.

Untuk mewujudkan kualitas mutu lulusan diperlukan program pengingkatan mutu Salah satu langkah yang dapat diambil untuk meningkatkan kualitas tersebut adalah dengan melalui quality control. Ishikawa mendefinisikan quality control sebagai proses untuk mengembangkan, merancang, memproduksi dan melayani produk berkualitas yang paling ekonomis, paling berguna, dan selalu memuaskan bagi konsumen. Melalui tawaran Ishikawa tentang quality control ini akan membawa kualitas output (produk) menjadi lebih baik.

Dalam konteks pendidikan, quality control adalah suatu usaha yang dilakukan oleh lembaga pendidikan untuk mengendalikan laju atau jalannya mutu sesuai dengan kemampuan masing-masing lembaga pendidikan. Dalam mengontrol mutu kita juga harus melakukan kendali mutu. Kontrol mutu pendidikan dapat diselenggarakan melalui berbagai model manajemen kendali mutu. Salah satu model manajemen yang

29 Muhammad Fadhli, “Manajemen Peningkatan Mutu Pendidikan," Tadbir: Jurnal Studi Manajemen Pendidikan 1, no. 2 (2017): 215-40, https://doi.org/10.46244/visipena.v4i2.218.

${ }^{30}$ Mardan Umar and Feiby Ismail, "Peningkatan Mutu Lembaga Pendidikan Islam (Tinjauan Konsep Mutu Edward Deming Dan Joseph Juran)," Jurnal Ilmiah Iqra' 11, no. 2 (2018): 15-16, https://doi.org/10.30984/jii.v11i2.581.

${ }^{31}$ Syafaruddin, Manajemen Mutu Terpadu Dalam Pendidikan: Konsep, Strategi Dan Aplikasi (Jakarta: Grasindo, 2002), 35 . 
dapat digunakan adalah model PDCA (plan, do, check, action) yang akan menghasilkan pengembangan berkelanjutan mutu pendidikan (education quality). ${ }^{32}$

Pengembangan Ishikawa terhadap konsep PDCA dengan enam langkahnya tersebut dapat menjadi alternative manajemen yang dapat dilaksanakan untuk quality control. Setiap langkah yang dikembangkan Ishikawa dapat dilaksanakan secara sistematis dan benar oleh lembaga pendidikan. Dengan demikian, mutu output pendidikan dapat tercapai dengan maksimal.

Setiap lembaga pendidikan selalu berusaha untuk mengendalikan mutu sesuai dengan keadaan dan kemampuan masing-masing lembaga pendidikan. Hal ini bertujuan untuk mempermudah dalam usaha pengendalian mutu itu sendiri. Usaha pengendalian mutu sekolah dapat dilakukan dengan: Pertama, pengendalian mutu tidak dapat menghasilkan suatu manfaat yang optimal. Kedua, usaha tersebut merupakan suatu kegiatan manajemen ilmiah yang ditujukan kepada sasaran tertentu dengan mengikuti siklus manajemen. Ketiga, pengendalian mutu merupakan usaha memperbaiki kualitas lulusan (output). Keempat, pengendalian mutu merupakan usaha untuk mengikuti siklus manajemen PDCA dengan mempertimbangkan unsur 5 $\mathrm{M}$ yaitu: manusia (man), mesin (machine), bahan (material), uang (money), dan metode. ${ }^{33}$

Sementara itu, konsep Ishikawa yang lain juga dapat diterapkan dalam peningkatan kualitas output pendidikan yaitu penerapan QC Circle. Saat ini QC Circle ini lebih dikenal dengan Gugus Kendali Mutu (GKM). Gugus ini bertugas untuk melakukan quality control. Untuk dapat melaksanakan tugas dengan baik, GKM ini haruslah terdiri dari orang-orang yang secara sukarela mau bekerja untuk peningkatan kualitas sebagaimana yang disyaratkan oleh Ishikawa. Dalam konteks pendidikan (sekolah/madrasah) dapat dilaksanakan oleh orang-orang yang berada pada top management, missal kepala sekolah/madrasah dan wakil-wakilnya. Sedangkan dalam konteks Pendidikan Tinggi dapat dilaksanakan oleh LPM atau GKM di tingkat fakultas/program studi.

Sekolah bisa menghasilkan lulusan yang bermutu apabila penyelenggaraan pendidikan mutunya juga terjamin. Mutu pendidikan akan terjamin ketika kepala sekolah/madrasah atau orang yang berada pada level manajemen puncak mampu melaksanakan fungsi quality control ini dengan baik dan dibarengi komponen pendidikan yang berkualitas juga atau dalam bahasa lainnya adanya terjadi sinergitas yang berorientasi pada mutu pendidikan antara pemimpin dengan seluruh civitas akademika di lembaga pendidikan tersebut.

b. Dasar penyusunan strategi peningkatan mutu pendidikan berbasis cause and effect

Suatu organisasi mempunyai tujuan yang ingin dicapai. Untuk mencapai tujuan diperlukan suatu strategi. Menurut Sanjaya, strategi merupakan metode yang digunakan untuk memperoleh kesuksesan datau keberhasilan dalam mencapai tujuan. Sedangkan Menurut Chandler, strategi merupakan alat untuk mencapai tujuan organisasi dalam kaitannya dengan tujuan jangka panjang, program tindak lanjut, serta prioritas alokasi sumber daya. ${ }^{34}$ Dari dua pendapat diatas dapat disimpulkan bahwa strategi merupakan metode yang digunakan dalam sebuah organisasi untuk mencapai tujuan yang telah ditetapkan. Dalam menentukan strategi terlebih dahulu harus

\footnotetext{
${ }^{32}$ Aminatul Zahroh, "Total Quality Management: Capaian Kualitas Output Melalui Sistem Kontrol Mutu Sekolah," CENDEKIA: Journal of Education and Teaching 9, no. 1 (2015): 89, https://doi.org/10.30957/cendekia.v9i1.54.

33 Shigeru Mizuno, Sejarah Pengendalian Mutu Terpadu Di Jepang, Terjemah: Eko Henriyanto Dan BN. Marbun (Jakarta: PT. Gramedia, 1993), 13-14.

${ }^{34}$ Zahroh, "Total Quality Management: Capaian Kualitas Output Melalui Sistem Kontrol Mutu Sekolah," 80.
} 
menentukan rumusan tujuan yang jelas dan menentukan faktor-faktor yang dapat mempengaruhi keberhasilan dalam pencapaian tujuan. setiap organisasi pasti berharap bahwa setiap tujuan yang telah ditetapkan dapat meninkatkan mutu organisasi.

Strategi sekolah merupakan kebijakan-kebijakan yang penting dari sekolah untuk mencapai tujuan yaitu meningkatkan dan mengembangkan mutu sekolah. Strategi yang tepat dapat berdapak pada keberhasilan sekolah dalam mencapai tujuannya. Untuk mendapatkan strategi yang tepat, sekolah memerlukan mengetahui informasi tentang faktor-faktor di sekolah yang dapat mendukung keberhasilan dalam mencapai tujuan. Oleh karenanya, sekolah perlu menganalisis faktor-faktor tersebut. Dengan melakukan analisa diharapkan dapat memberikan informasi yang dapat dijadikan acuan dalam menyusun strategi sehingga mendapatkan mutu pendidikan yang baik.

Teknik analisa untuk mengidentifikasi sebab akibat dari permasalahan melalui diagram Ishikawa. Diagram Ishikawa atau Fishbone diagram (diagram tulang ikan) sering juga disebut Cause-and-Effect Diagram merupakan teknik untuk memetakkan seluruh faktor yang menyebabkan terjadinya masalah pada hasil yang diinginkan. Adapun tujuan dari diagram Ishikawa adalah untuk mendata seluruh faktor yang mempengaruhi mutu dari sebuah proses dan untuk memetakan inter-relasi antar faktor-faktor. ${ }^{35}$

Ishikawa menuturkan bahwa Cause and Effect Diagram digunakan tidak hanya untuk masalah QC akan tetapi dapat diterapkan untuk solusi dari masalah apa pun. Tujuannya adalah untuk mendapatkan hasil; karena tindakan harus diambil terhadap penyebabnya, jika kita tidak tahu hubungan antara sebab dan akibat dari suatu masalah, maka tidak akan dapat mengambil tindakan apa pun untuk menyelesaikannya. Cause and Effect Diagram menunjukkan penyebab yang paling jelas sehingga dapat diambil tindakan dengan cepat. Diagram Ishikawa dirancang dalam konteks praktis dengan fokus pada pemahaman yang lebih dalam tentang "mengapa-nya" dalam proses. Diagram Ishikawa dapat digunakan untuk memecah secara efektif masalah ke dalam matriks hubungan sebab akibat. Diagram tersebut digunakan untuk mengidentifikasi penyebab setelah difokuskan definisi masalah dalam tim atau QC Circle, beberapa individu dapat memberikan saran dan pendapat tentang faktor kausal apa saja yang paling berpengaruh yang menyebabkan efek atau masalah. Dengan demikian, diagram ini juga bisa diimplementasikan dalam konteks lembaga pendidikan untuk mengetahui penyebab dari permasalah yang timbul dari penyelenggaraan pendidikan, serta untuk menentukan strategi apa yang tepat yang bisa diambil untuk memecahkannya.

Untuk memperkuat, penulis memaparkan hasil penelitian saudara Wara Hapsari Oktriany, dkk. ${ }^{36}$ Tentang Strategi Peningkatan Mutu Pendidikan Menggunakan Diagram Ishikawa di SMA Negeri Suruh. Hasil penelitian menunjukkan bahwa mengenai faktor-faktor yang mempengaruhi menurunnya mutu lulusan di SMA $\mathrm{N}$ 1 Suruh menggunakan diagram Ishikawa, secara visual menunjukkan hasil identifikasi penyebab suatu masalah sebagaimana diagram berikut:

\footnotetext{
${ }^{35}$ Edward Sallis, Total Quality Management In Education (Yogyakarta: IRCiSoD, 2008), 202.

${ }^{36}$ Wara Hapsari Oktriany, Ria Triastuti, and Yusia Sri Prajoko, "Strategi Peningkatan Mutu Pendidikan Menggunakan Diagram Ishikawa Di SMA NEgeri ı Suruh," Proceeding Seminar Nasional Pendidikan Ekonomi Dan Bisnis, no. November (2015).
} 


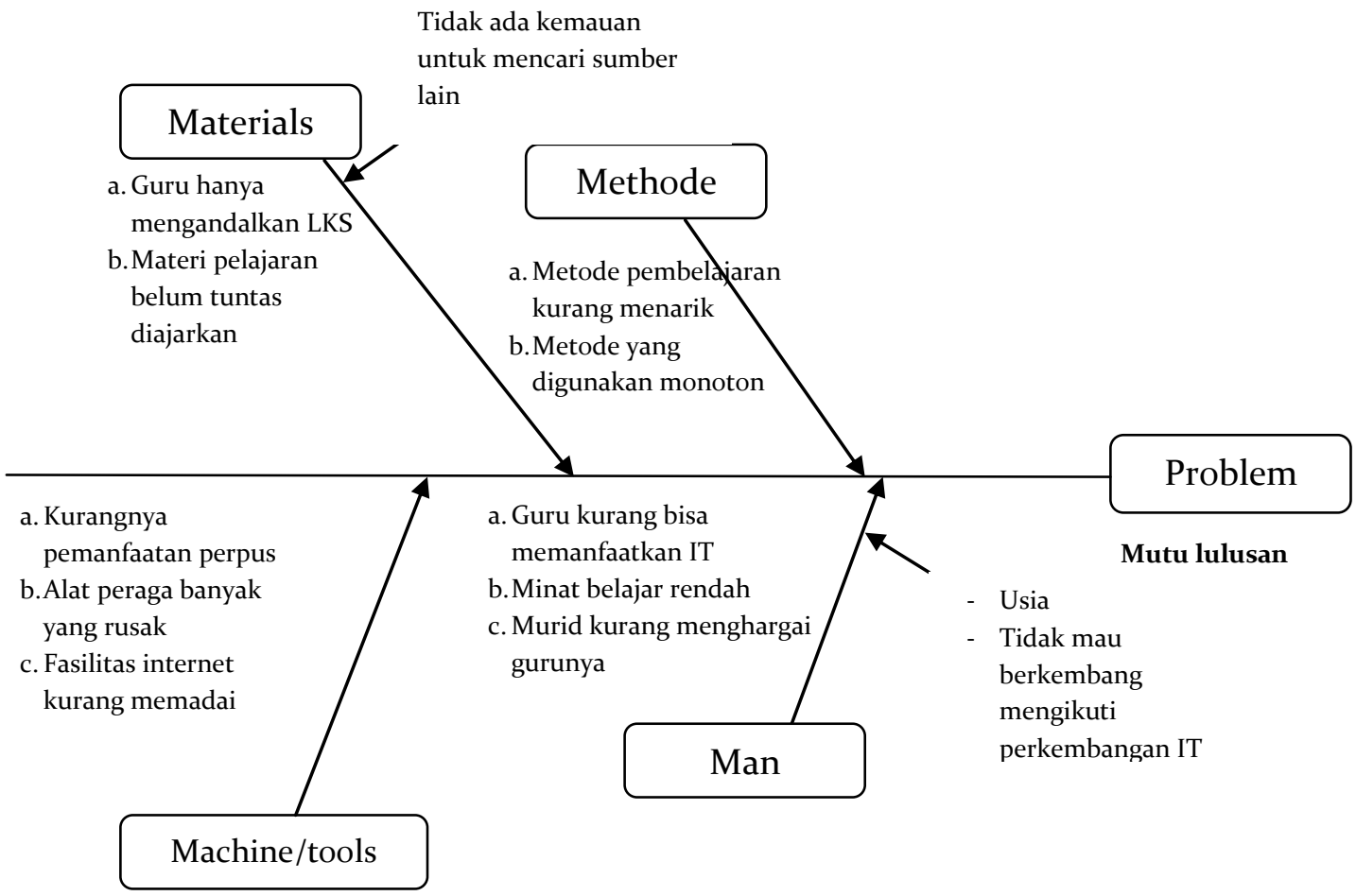

Gambar 4. Diagram Ishikawa Menurunnya Mutu Lulusan

Berdasarkan Diagram Ishikawa menurunnya mutu lulusan di atas dapat dijelaskan bahwa menurunnya mutu sekolah disebabkan oleh beberapa faktor yang menjadi penyebab masalah yaitu sumber daya manusia, tool/sarana prasarana, metode pembelajaran dan material/sumber belajar.

Berdasarkan rangkuman diskusi pada sesi brainstorming dalam menyusun diagram Ishikawa, maka SMAN 1 Suruh dapat mengetahui apa saja yang menjadi penyebab rendahnya mutu lulusan, sehingga dapat ditentukan strategi apa yang akan digunakan untuk meningkatkan mutu lulusannya. Secara visual hasilnya dipaparkan pada tabel berikut:

Tabel 1. Penyebab Rendahnya Mutu Lulusan dan Strategi Peningkatannya

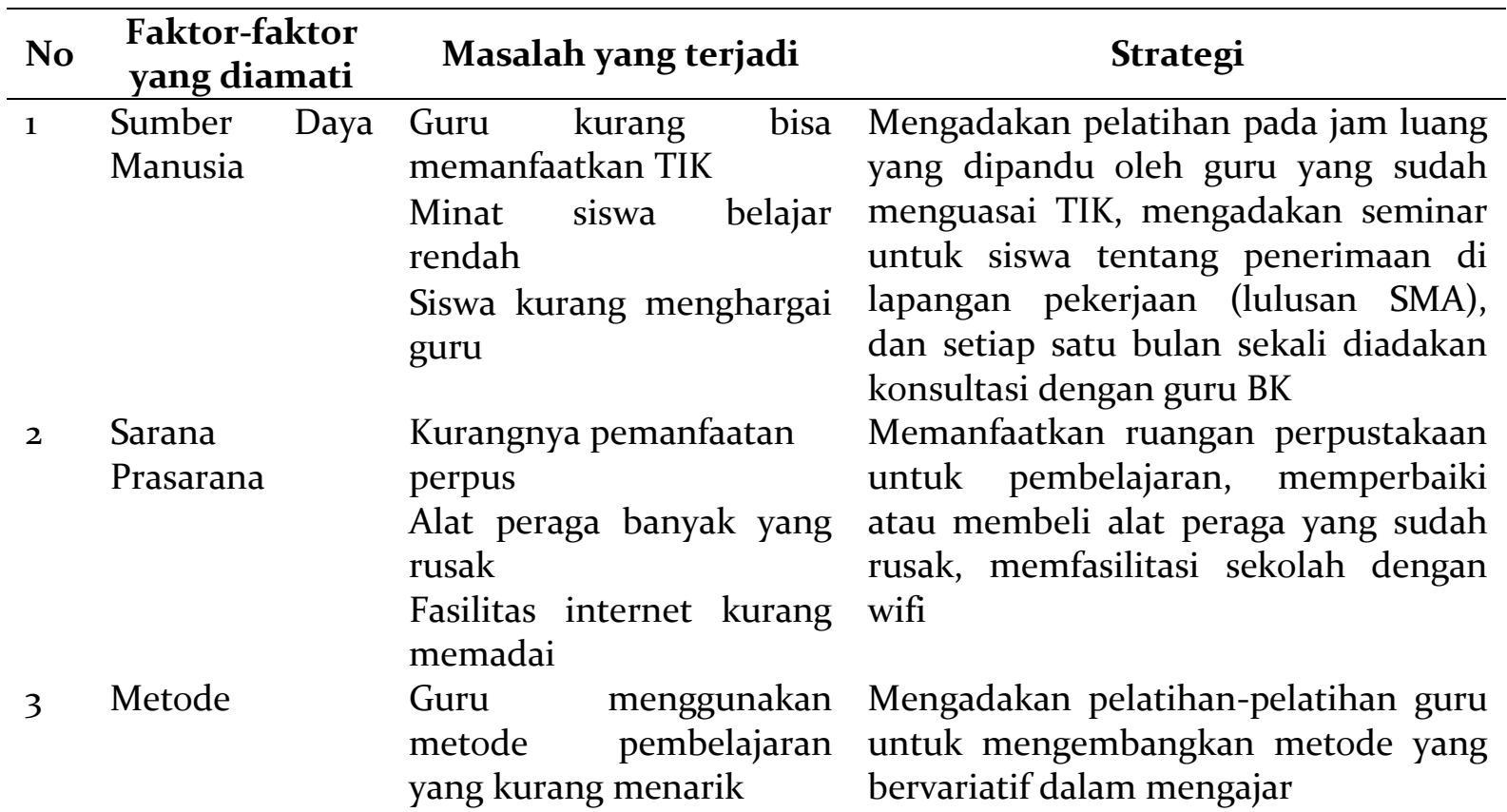




\begin{tabular}{|c|c|c|c|}
\hline No & $\begin{array}{l}\text { Faktor-faktor } \\
\text { yang diamati }\end{array}$ & Masalah yang terjadi & Strategi \\
\hline \multirow{3}{*}{4} & \multirow{3}{*}{ Materials } & $\begin{array}{l}\text { Guru menggunakan } \\
\text { metode yang monoton } \\
\text { (tidak bervariatif) }\end{array}$ & \\
\hline & & $\begin{array}{l}\text { Guru hanya } \\
\text { mengandalkan LKS }\end{array}$ & $\begin{array}{l}\text { Mengadakan pelatihan pembuatan } \\
\text { bahan ajar dan evaluasi yang sesuai } \\
\text { dengan karakteristik siswa }\end{array}$ \\
\hline & & $\begin{array}{l}\text { Materi pelajaran belum } \\
\text { tuntas diajarkan }\end{array}$ & $\begin{array}{l}\text { Pengaturan waktu pembelajaran } \\
\text { dengan tepat sesuai dengan program } \\
\text { semester }\end{array}$ \\
\hline
\end{tabular}

Berdasarkan pemaparan hasil penelitian tersebut maka dapat disimpulkan bahwa penyusunan dan penetapan strategi peningkatan mutu pendidikan dapat dilakukan dengan menggunakan Cause and Effect Diagram Ishikawa. Melalui diagram ini, penyelenggara pendidikan akan mengetahui faktor-faktor penyebab terjadinya masalah berdasarkan hasil brainstorming di antara seluruh komponen penyelengara pendidikan. Dengan diketahui penyebabnya tersebut, maka akan dapat ditentukan strategi apa yang tepat yang bisa diterapkan untuk mengatasi permasalah tersebut, sehingga peningkatan mutu pendidikan pun dapat tercapai dengan maksimal.

\section{Kesimpulan}

Upaya peningkatan mutu yang dilakukan oleh Ishikawa adalah dengan menerapkan sistem Quality Control. Dalam upayanya ini Ishikawa menganjurkan untuk membentuk QC Circle yang terdiri dari kelompok kecil pekerja yang bekerja sama dengan prinsip saling menguntungkan untuk melakukan kegiatan quality control secara sukarela. Selain itu, Ishikawa juga menganjurkan untuk menggunakan 7 (tujuh) alat kualitas dasar yang salah satunya yang paling terkenal adalah Cause and Effect Diagram. Diagram ini dapat digunakan untuk memecah secara efektif masalah ke dalam matriks hubungan sebab akibat oleh tim atau QC Circle, beberapa individu dapat memberikan saran dan pendapat tentang faktor kausal apa saja yang paling berpengaruh yang menyebabkan efek atau masalah.

Konsep mutu Ishikawa ini dapat diimplementasikan dalam dunia pendidikan di antaranya untuk: 1) Peningkatan Mutu Output Pendidikan melalui Quality Control; dan 2) Dasar penyusunan strategi peningkatan mutu pendidikan berbasis cause and effect. Konsep peningkatan mutu Ishikawa ini memberikan motivasi kepada lembaga pendidikan untuk melakukan manajemen mutu yang baik yang salah satunya adalah konsistensi dalam melakukan quality control dengan melalui pembentukan QC Circle (Gugus Kendali Mutu) dan penggunaan alat control salah satunya adalah Cause and Effect Diagram. Dengan demikian, lembaga pendidikan dapat meningkatkan mutunya dengan mengetahui akar penyebab masalah yang terjadi serta menentukan strategi peningkatan mutu yang tepat.

\section{References}

Ali, Lukman. Kamus Besar Bahasa Indonesia. Jakarta: Balai Pustaka, 1995.

Baitanayeva, Bakhyt, Zhanara Aubakirova, Aida Aitbembetova, and Aida Sansyzbayeva. "Problems Of Improving The Quality Of Education." E3S Web of Conferences 159 (2020): 
1-11. https://doi.org/10.1051/e3sconf/202015909002.

Balbirnie, Marc. "Proffesor Kaoru Ishikawa: A Man In Search Of Harmony." IASSC Lean Six Sigma Green Belt, 1989, 1-5.

Best, M., and D. Neuhauser. "Kaoru Ishikawa: From Fishbones To World Peace." Quality E Safety in Health Care 17, no. 2 (2008): 150-52. https://doi.org/10.1136/qshc.2007.025692.

Fadhli, Muhammad. "Manajemen Peningkatan Mutu Pendidikan." Tadbir: Jurnal Studi Manajemen Pendidikan2 1, no. 2 (2017): 215-40. https://doi.org/10.46244/visipena.v4i2.218.

Fathurrohman, Muhammad. "Pengembangan Budaya Religius Dalam Meningkatkan Mutu Pendidikan." Ta'allum: Jurnal Pendidikan Islam 4, no. 1 (2016): 19-42. https://doi.org/10.21274/taalum.2016.4.1.19-42.

Goetsch, David L., and Stanley Davis. Quality Management for Organizational Excellence: Introduction to Total Quality. Pearson Education Limited, 2014.

Indonesia, Presiden Republik. "Undang-Undang Republik Indonesia Nomor 20 Tahun 2003 Tentang Sistem Pendidikan Nasional.” Jakarta, 2003.

Ishikawa, Kaoru. Guide to Quality Control. Tokyo: Asian Productivity Organization, 1976.

- - - Introduction to Quality Control. 3rd ed. 3A Corporation, 1990.

- - What Is Total Quality Control? The Japanese Way. Englewood Cliffs: Prentice-Hall, 1985 .

Kondo, Yoshio. "Kaoru Ishikawa: What He Thought and Achieved, a Basis for Further Research.” Quality Management Journal 1, no. 4 (July 25, 1994): 86-90. https://doi.org/10.108o/10686967.1994.11918666.

Mizuno, Shigeru. Sejarah Pengendalian Mutu Terpadu Di Jepang, Terjemah: Eko Henriyanto Dan BN. Marbun. Jakarta: PT. Gramedia, 1993.

Mulyasa, E. Standar Kompetensi Dan Sertifikasi Guru. Bandung: PT. Remaja Rosdakarya, 2007.

Mundiri, Akmal. "Strategi Lembaga Pendidikan Islam Dalam Membangun Branding Image." Pedagogik: Jurnal Pendidikan 3, no. 2 (2016): 58-72.

Oktriany, Wara Hapsari, Ria Triastuti, and Yusia Sri Prajoko. "Strategi Peningkatan Mutu Pendidikan Menggunakan Diagram Ishikawa Di SMA NEgeri 1 Suruh.” Proceeding Seminar Nasional Pendidikan Ekonomi Dan Bisnis, no. November (2015).

Sallis, Edward. Total Quality Management In Education. Yogyakarta: IRCiSoD, 2008.

Sugimoto, Tatsuo. "Father of the QC Circle : Prof. Kaoru Ishikawa." Kaoru Ishikawa, The Man and Quality Control, no. 319 (2015): 1-30.

Syafaruddin. Manajemen Mutu Terpadu Dalam Pendidikan: Konsep, Strategi Dan Aplikasi. Jakarta: Grasindo, 2002. 
Umar, Mardan, and Feiby Ismail. "Peningkatan Mutu Lembaga Pendidikan Islam (Tinjauan Konsep Mutu Edward Deming Dan Joseph Juran).” Jurnal Ilmiah Iqra' 11, no. 2 (2018). https://doi.org/10.30984/jii.v11i2.581.

Watson, Greg. “The Legacy Of Ishikawa." Quality Progress 37, no. 4 (2004): 54-57.

Zahroh, Aminatul. "Total Quality Management: Capaian Kualitas Output Melalui Sistem Kontrol Mutu Sekolah." CENDEKIA: Journal of Education and Teaching 9, no. 1 (2015): 79. https://doi.org/10.30957/cendekia.v9i1.54 